Article

\title{
Improving Regulation and the Role of Natural Risk Knowledge to Promote Sustainable Low Enthalpy Geothermal Energy Utilization
}

\author{
Giorgio De Giorgio ${ }^{1, *}$, Michele Chieco ${ }^{2}$, Pier Paolo Limoni ${ }^{1}$, Livia Emanuela Zuffianò ${ }^{1}{ }^{(\mathbb{D}}$, \\ Vittoria Dragone ${ }^{1}$, Annarita Romanazzi ${ }^{1}$, Rossella Pagliarulo ${ }^{1}{ }^{1}$, Giuseppe Musicco ${ }^{2}$ and \\ Maurizio Polemio ${ }^{1}$ (D) \\ 1 CNR-IRPI, National Research Council—Research Institute for Hydrogeological Protection, 70100 Bari, Italy; \\ p.limoni@ba.irpi.cnr.it (P.P.L.); l.zuffiano@ba.irpi.cnr.it (L.E.Z.); v.dragone@ba.irpi.cnr.it (V.D.); \\ a.romanazzi@ba.irpi.cnr.it (A.R.); r.pagliarulo@ba.irpi.cnr.it (R.P.); m.polemio@ba.irpi.cnr.it (M.P.) \\ 2 Apulia Regional Council—Study and Support to Legislation and Guarantee of Rights Policies Department, \\ 70100 Bari, Italy; chieco.michele@consiglio.puglia.it (M.C.); musicco.giuseppe@consiglio.puglia.it (G.M.) \\ * Correspondence: g.degiorgio@ba.irpi.cnr.it; Tel.: +39-080-592-9600
}

Received: 26 August 2020; Accepted: 15 October 2020; Published: 19 October 2020

check for updates

\begin{abstract}
The use of geothermal energy resources to support anthropogenic activities have a long-lasting tradition, renewed in recent decades with the increasing use of low enthalpy geothermal energy (LEG) with combined systems of heat pumps and geothermal exchange, exploiting the enormous thermal capacity and very low temperature variability of subsoil, including rocks and water. The further potential global increase of LEG use could be enormous, although LEG is already the main geothermal energy sources in Europe, contributing significantly to reach $2030 \mathrm{UN}$ sustainable development goals (SDGs) on renewable energy resources, as a further leg to support all necessary efforts for these scopes. This research pursues LEG spreading improving knowledge on limitations of guidelines, technical regulations and/or laws, briefly rules, especially in terms of potential risks or limitations due to environmental constrains or natural phenomena. A global documentary research, including scientific articles, books, technical reports from qualified institutions, technical standards, guidelines, regulations, and laws, was realized with three different groups of keywords. A total of 161 documents were selected after some steps, including quality check. Identical English and Italian keyword sets were used to span from an international global scale to the complex local scale which characterizes the Italian experience. A complex sheet was filled in for each document, supporting data discussion, planned with a geographical criterion, from global to local. The system of rules resulted worldwide inhomogeneous and complex, with high differences from countries, nations or regions, also at local scale. The low quality or the absence of simple and careful "rules" emerged an important obstacle to LEG diffusion that can guarantee sustainability and the absence of natural risks. Main virtuous systems of rules were recognized as very useful to promote LEG spreading but these are still uncommon. The discussion of optimal experiences and the overview of potential natural risks due to LEG complete the paper.
\end{abstract}

Keywords: low-enthalpy geothermal resources; heat pumps; geothermal exchange; sustainable development goals; renewable energy; directives; regulations; natural risks

\section{Introduction}

Italy was the first country in the world to use high temperature (greater than $100{ }^{\circ} \mathrm{C}$ ) geothermal energy for electricity production in the Larderello site (Tuscany); this pioneering experience started the use of heat of geothermal fluids for electricity production spreading the use of the word "geothermal" [1]. 
On a global scale, the geothermal electricity production is possible in narrow areas and the increase is limited by natural conditions [2,3]. The subsoil use for heat exchange is progressively growing due to systems based on low-enthalpy geothermal resources (LEG), which include the very low enthalpy, in combination with the spreading of heat pumps.

LEG is potentially applicable without significant geographical, territorial and/or climatic limitations [2]. For these reasons, LEG is the first European geothermal source for installation number, installed capacity and produced energy (66.5\% of the total, while $26.2 \%$ and $7.3 \%$ are direct use of heat and electricity production, respectively) [4].

LEG applications generally use heat pumps for climatization, sanitary hot water, and many industrial uses. LEG includes any type of open or closed loop systems for heat exchange $[5,6]$. The open loop is the case in which groundwater is withdrawn by an aquifer (secondly by surface water resources), where it is usually injected after heat exchange. The closed loop uses a heat transfer fluid, generally water in which somewhere additives can be useful, i.e., to avoid fluid freezing, circulating inside tubes, called geothermal probes.

The probes are installed with vertical or horizontal schema. A unique vertical probe, sometimes called borehole heat exchanger, can be enough; otherwise, an interconnect group of probes create a borehole field. The probes can be also horizontal, in a pit or in a trench, at low depth, generally less than $4 \mathrm{~m}$ below ground surface. The latter case is of secondary relevance for this paper.

LEG includes applications in which the whole system, including rocks and fluids at involved depths, is less than $90^{\circ} \mathrm{C}$ [7-9]. The maximum depth is generally no more than $300-400 \mathrm{~m}$ below the ground surface due to the high cost increase respect to benefits for increasing depth.

The use of depth (D) threshold to define low geothermal application, called "shallow geothermal energy" applications, is ruled by some EU member state regulations (i.e., $300 \mathrm{~m}$ for Slovenia and Austria). This choice could be considered a simple and univocal geometric limit within LEG applications.

The LEG strategic potentiality is high for the achievement of many targets of the sustainable development goals (SDGs) of the UN Agenda 2030 (United Nations, 2019), an action program on which 162 countries and territories work together (https://unsdg.un.org/). This technology could actively help to achieve the specific Agenda objectives 7.2 and 7.3 by 2030, which aim to "increase substantially the share of renewable energy in the global energy mix" and "double the global rate of improvement in energetic efficiency," respectively. Other LEG-related advantages can be considered the emission decrease of greenhouse gas and some atmospheric pollutants and the management cost lowering; the main disadvantage is higher installation cost, which is nevertheless amortized in a few years [10-12].

The real spread of the LEG applications, with important differences at the global and European scales, is still far from an optimal level compared to its potentiality [5]. This is confirmed at national level, i.e., in Italy, where many studies have shown high LEG potentialities for many applications, as demonstrated by detailed studies even on a regional scale [13-18]. This low and slow LEG diffusion could be due to the global lack of clear, simple and reliable technical regulations and laws that explain how and where to implement LEG solutions without negative effects, taking into account geological and environmental peculiarities [19].

The article deals with these difficulties starting from an accurate census of international and European regulations, focusing on national experiences, with the regional and sub-regional details in the case of Italy.

The attention will be drawn to those experiences worthy of sharing and deepening. Our primary aim is contributing to the consolidation of widely applicable, effective and shared rules in order to promote the dissemination of the LEG in the respect of sustainability and safety.

Focusing on the environmental constrains, the attention is focused on geological and hydrogeological peculiarities that, site by site, can determine the feasibility and usefulness or risks of LEG and, in the alternative, the different solutions of LEG to pursue environmental optimal solutions. In addition, the natural and geological LEG risks are recognized and listed. This applied research 
supports the action of the Department of "Study and Support to Legislation and Guarantee of Rights Policies" of the Apulian Regional Council.

\section{Data and Methods}

The research started with a detailed and methodical research of technical-scientific documents dealing with the use of geothermal energy, focusing on low enthalpy applications. It considered technical reports drawn up by public institutions or trade associations, scientific articles, technical standards, directives or regulations. In the following, each of these types of information source will be defined as "document". In a first step, documents were searched with English keywords using digital databases and web sources. The research was repeated in Italian, to refine the results at the detailed national scale. Three groups of keywords ( 30 keywords as total) were selected to focus the document selection considering the type of document, geothermal application and/or possible natural effects of risks.

Useless, superfluous or redundant documents were discarded. A sheet was filled for each selected document. The sheet includes bibliographic data and three sections: a document summary focused on the research purposes, useful ideas, information or examples for regulations or laws, and any information on experiences related to natural risks. A finishing or second step of the document research considered the references cited by available documents of the previous step with the purpose to fill up some eventual gaps of the first-step research criteria.

The final database includes 161 documents. The documents can be divided in four groups: scientific, informative, technical, and legal documents.

Scientific documents are mainly articles published in international journals but there are some books, conference papers and theses; they correspond to $34 \%$ of the database.

The informative scientific documents are generally available for free download; they include technical, didactic or dissemination articles, sources, lessons or presentations, documents generally edited by the scientific/academic community; they correspond to $26 \%$. The technical documents, including technical reports, are $12 \%$, while the largest group, equal to $40 \%$, are normative/legal documents, mostly legislative official documents.

About $14 \%$ of the documents are theoretical, methodological or didactic, so that they are not geographically localizable. Considering the remaining documents, $64 \%$ of the total refer to Europe (Figure 1). The remaining documents concern America, Asia, Africa, and Oceania, in decreasing percentage order. Focusing on the country level, it should be considered that many documents concern more than one country. Of the database, $14 \%$ concerns all countries of the European Union, being mainly regulatory provisions. Excluding documents relating to all EU members and Italy, on which the research was detailed, the number of documents concerning France, Switzerland, Germany, and the UK prevails. 


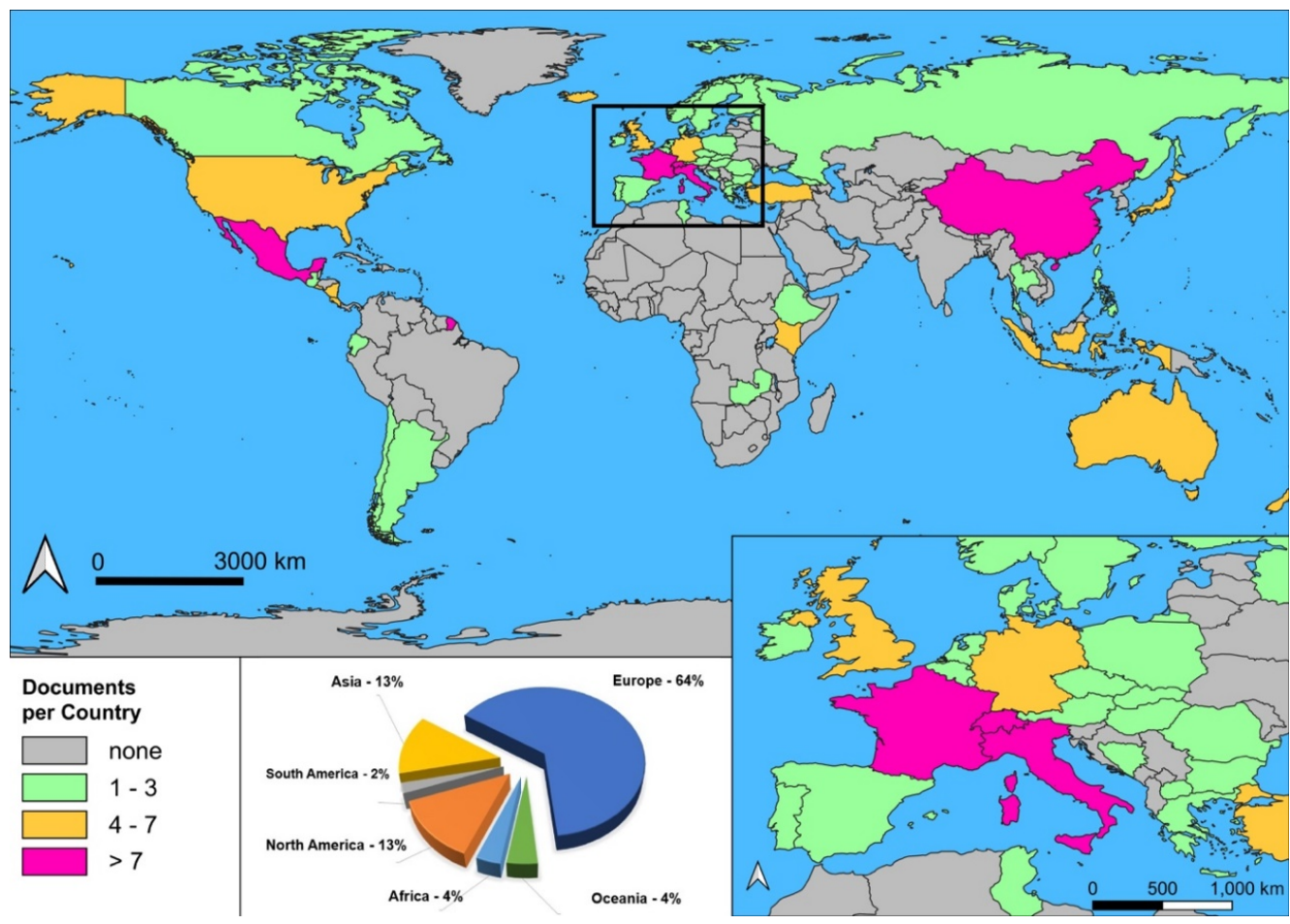

Figure 1. National occurrence map of selected documents and continental percentage. National (or subnational) and international (more than one country involved) documents were considered.

In the Italian context, the documents on Tuscany, Veneto and Piedmont Regions prevail; these regions are in northern Italy, where the regional regulation has existed for years (Figure 2).

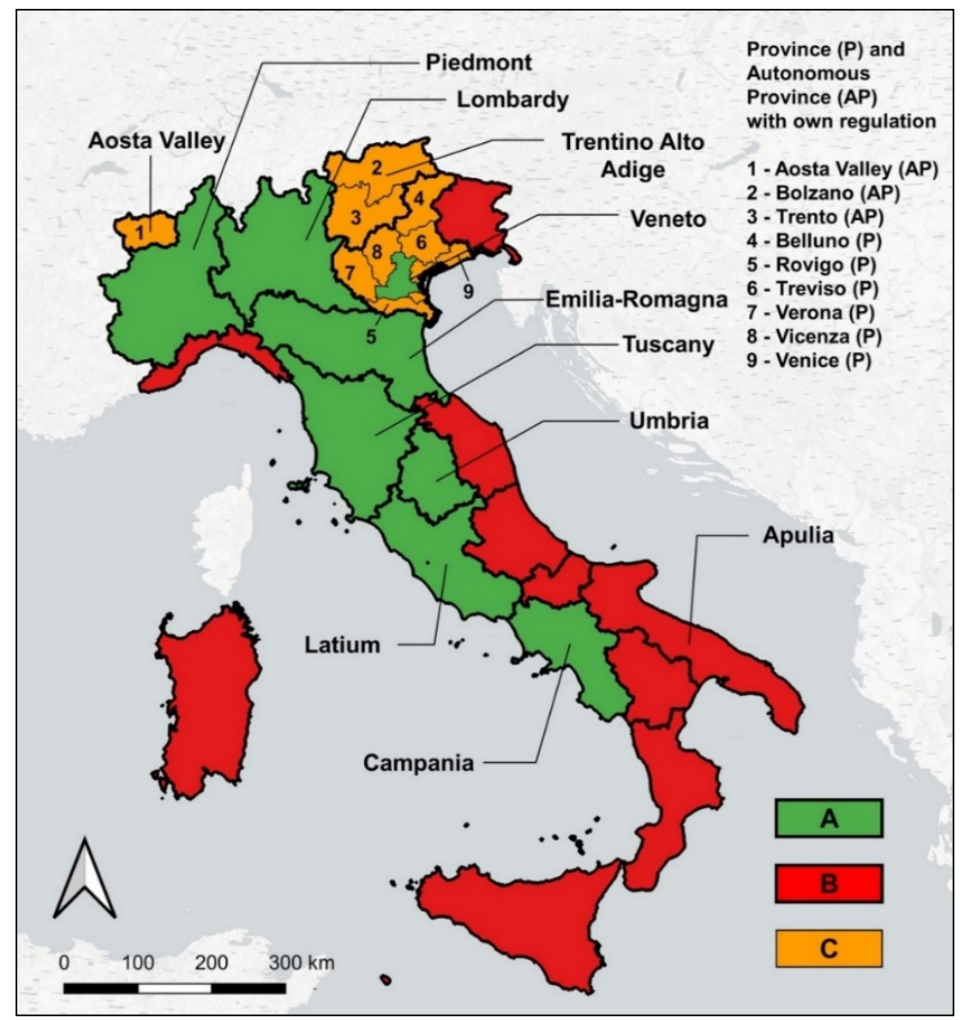

Figure 2. Overview of the low enthalpy geothermal energy (LEG) Italian regulation. (A) region with regulation; (B) region without regulation; (C) province with regulation. 


\section{Results}

The results are described from a global schematic view to the detailed Italian local situation.

The global overview highlights inhomogeneous interest in LEG applications that could be simply and only due to the location of the working group and the aims of the research. Both these characteristics could overestimate the role of European and Italian experiences. Checking other global factors, it seems realistic that national social and economic conditions, mainly population trend, energy demand and availability of other energy sources at very low cost, and economic development, and natural conditions prone to geo-exchange, mainly climate, lithology, and groundwater availability), can be relevant, contributing to explaining this variability (https://worldmapper.org, https://www.whymap.org).

Outside Europe, Mexico, China, the USA, and Australia show higher numbers of documents.

A few countries have regulated LEG outside Europe: USA, Mexico, Ecuador, China, Australia, Indonesia, and Philippines. These rules are generally defined in the context of legal regimes regulating the use of water resources. The minimum distance between LEG systems is ruled in China and USA. The outline of these documents seems almost inhomogeneous and fragmented in terms of application, classification, and regulation and without useful references to potential risks, resulting in low interest for the paper's purposes [19].

The increasing use of renewable energy sources (RES) has been a priority objective of the European energy policy since 1986, as set out in the European Council resolution (OJ C 241/1986) which included it among the priority energy objectives to be implemented by 1995 . This purpose was more pursued in the next years, until 2018, as testified by the adoption of Directives (77/2001/EC, 91/2002/EC, and 28/2009/EC) and Regulations (31/2010/EU, 1999/2018/EU, 2001/2018/EU, and 2002/2018/EU). This legal framework has progressively defined reliable and precise RES priority objectives, with some positive effects, which include a powerful boost to the use of LEG. The whole set of these programmatic initiatives on energy has not been detailed up to include guidelines, constraints, or requirements promoting or imposing national legislation or regulation in each sector of RES. The overall EU regulatory framework seems not constraining enough, particularly for LEG, one of the most effective RES for environmental benefits $[19,20]$. As a result of this framework, many European countries have not specific legislation on LEG or the regulation is so generic to be considered enough to support a widespread and safe diffusion of LEG. Positive and opposite experiences concern Germany, France, The Netherlands, Austria and Switzerland, which is not a member of the EU.

In Germany, a federal state, a concession is required to set up a LEG plant, which is issued by the water authorities of the specific Land, one state of the German Federation, according to prescriptive guidelines, autonomously approved by each state authority without a federal unitary framework (Table 1).

Table 1. Comparison of main hazardous conditions factors taken into account in selected national LEG regulation in Europe.

\begin{tabular}{|c|c|c|}
\hline Environmental or Risk Factors & Nation & Limitation \\
\hline \multirow{2}{*}{ Artesian or confined aquifers } & Austria & In the remaining cases, a specific approval is required \\
\hline & Germany & $\begin{array}{l}\text { Land dependent: prohibition or there are guidelines that impose specific requirements } \\
\text { (including installation equipment) }\end{array}$ \\
\hline \multirow[b]{2}{*}{ Shallow or phreatic aquifers } & Austria & It is allowed if LEG depth is lower than $2 \mathrm{~m}$ of depth to groundwater \\
\hline & Germany & $\begin{array}{l}\text { In some floodplains with very shallow aquifers, prohibition or specific studies } \\
\text { are required }\end{array}$ \\
\hline
\end{tabular}


Table 1. Cont.

\begin{tabular}{|c|c|c|}
\hline Environmental or Risk Factors & Nation & Limitation \\
\hline \multirow{4}{*}{ Multi-strata aquifer } & Austria & Prohibition \\
\hline & France & $\begin{array}{l}\text { Official national maps represent permitted areas and those where an impact assessment } \\
\text { is required }\end{array}$ \\
\hline & Germany & $\begin{array}{c}\text { Land dependent: prohibition or to be authorized under the control/monitoring of a } \\
\text { hydrogeologist expert }\end{array}$ \\
\hline & Switzerland & Forbidden by federal guidelines \\
\hline \multirow{4}{*}{$\begin{array}{l}\text { Hydrogeological protection } \\
\text { zone (HPZ) }\end{array}$} & Austria & $\begin{array}{c}\text { There are } 3 \text { different HPZ sub-zones: prohibition for type I; specific and different } \\
\text { limitations for type II and III. }\end{array}$ \\
\hline & France & Official national maps represent prohibition areas \\
\hline & Germany & $\begin{array}{l}\text { Land-dependent: prohibition prevails (sub-zone types I and II) while risk analysis or } \\
\text { some areal exception permit installation in the sub-zone III }\end{array}$ \\
\hline & Switzerland & $\begin{array}{l}\text { Prohibition for all sub-zones, with the unique exception of horizontal closed loop } \\
\text { systems in the sub-zone III }\end{array}$ \\
\hline \multirow{3}{*}{ Gas occurrence } & Austria & Warning systems and special drilling and installation probes are mandatory \\
\hline & Germany & The use of specific tools and equipment for drilling is mandatory \\
\hline & Switzerland & $\begin{array}{c}\text { Canton dependent (there is not federal regulation in this case): prohibition or } \\
\text { authorization following specific investigations/assessments }\end{array}$ \\
\hline \multirow{4}{*}{ Instability conditions } & Austria & $\begin{array}{l}\text { Risk assessment is mandatory for evaporitic rocks, highly compressible soils and } \\
\text { landslide prone areas }\end{array}$ \\
\hline & France & $\begin{array}{l}\text { Official national maps represent permitted areas and those where an impact assessment } \\
\text { is required }\end{array}$ \\
\hline & Germany & Prohibition for evaporitic rocks \\
\hline & Switzerland & $\begin{array}{c}\text { Canton dependent (there is not federal regulation in this case): prohibition or } \\
\text { authorization following specific investigations/assessments }\end{array}$ \\
\hline
\end{tabular}

France rules LEG with a national standard regulation, which is based on a system of thematic national maps (Table 1). The mapping system distinguishes open and closed loops and the installation depth. These maps, worked out with high accuracy at the regional scale, distinguish three depth intervals below the ground surface: 10 to 50, 10 to 100, and 10 to $200 \mathrm{~m}$. Three types of zone are plotted: green, orange, and red; for each of these zones there are different rules for LEG installations. Green and orange permit different simplified procedures: in the former zone, a simple personal statement of the proposer is required; in the latter one, in addition to the proposer statement, a documented certification of compatibility is required from a professional expert. The national mapping considers some geo-hydrological and anthropogenic hazard factors: landslides, evaporitic rocks, artesian aquifers, multi-layer or semiconfined aquifers, natural or artificial caves, underground mining activities, well-known polluted areas. The positive environmental impact assessment is mandatory for LEG installations in the red zone.

In the Netherlands, open-loop systems are regulated by water resources legislation; the local authority authorization is necessary. Closed loop systems do not require authorization.

All LEG uses in Austria are regulated by the Federal Water Act (Table 1).

The approval procedures of LEG installations in Switzerland is ruled by the national legislation on water protection. It establishes a unique regulation framework respect to which each canton (Confederal Swiss Authority) is free to define detailed rules (Table 1). Each canton used autonomy in introducing some differences, mainly in relation to its territorial peculiarities, but in compliance with the national guidelines, edited by the Federal Office of the Environment.

The most interesting national regulations in Europe generally rule LEG in a context of environmental protection, focusing mainly on groundwater resources safeguarding, in the framework of the legislation regulating water resources utilization. The main national regulations of Europe were compared focusing on the practical consideration of hazardous conditions for LEG (Table 1), and hydrogeological protection zones (HPZs) of main aquifers, i.e., to protect groundwater sources for drinking use, are generally divided in three sub-zones, with different levels of protection, (I to III, the first of which is with maximum protection). The sub-zones were distinguished in terms of 
hydrogeological features. The hazards due to underground gas presence, and instability conditions, as due to landslide prone areas, karstic features, high soil compressibility, or rapid rock dissolution, complete the comparison (Table 1).

The Austrian regulation is the most comprehensive one, including all the considered sources of hazard. The Austrian approach is highly cautious because absolute prohibitions (artesian and multi-layer aquifers, and HPZ) prevail, while, in the remaining cases, detailed technical investigations are required or specific limitations are defined.

The most pragmatic approach, which supports tasks of both territorially competent authorities and proposers (users, professionals, and companies), is the French one. It summarizes into a national mapping system all the main current limitations.

All national legislations provide LEG prohibition at least in one HPZ sub-zone, often imposing prescriptions in the remaining sub-zones. The hazard related to gas occurrence or due potential instability conditions seems slightly less important: prohibitions or requirements of specific studies prevent the LEG installation involving evaporitic rocks, a rare but much feared situation; specific technical assessments are often required in the occurrence of highly compressible soils, landslide-prone areas, or in the case of caves.

The Italian legislation concerning geothermal energy started in 1927, with the royal decree 1443. It assimilated geothermal energy to mining resources, regulating research and exploitation with a unique national license regulation, requiring relevant technical and economical potentialities from applicants. No significant modifications occurred up to 1998, when the legislative decree 112/1998 delegated to the regions the competence on geothermal resource management.

The decree 4/2008, issued by the Ministry for the Environment, introduced for the first time some technical and procedural requirements for closed and open-loop LEG systems funded by the Revolving Fund implementing the Kyoto Protocol. It remained ineffective in all remaining cases.

The Law 99/2009, known as "development law," pursued geothermal growth following two paths: promoting free market competition for high-enthalpy geothermal resources and simplifying administrative procedures for the use of low-enthalpy and medium-enthalpy geothermal resources. The legislative decree (L.D.) 22/2010 defined low, medium, and high enthalpy geothermal resources considering the natural temperature of geothermal fluid less than $90^{\circ} \mathrm{C}, 90$ to $150{ }^{\circ} \mathrm{C}$, and greater than $150^{\circ} \mathrm{C}$, respectively. This decree reorganized the whole legislation on research and use of geothermal resources. It abolished the national monopolistic electricity market, ensured competitive criteria, and promoted RES production increase, including LEG utilization.

This decree together with the LD 28/2011 completed the transposition of the European Directive 28/2009, which promoted the RES use. The low local geothermal energy use was defined by law, including two types of installations: geothermal electricity production with power $(\mathrm{P})$ less than $2 \mathrm{MW}$ (obtained by heat geothermal fluid withdrawn by well $400 \mathrm{~m}$ in depth as maximum, in the hypothesis of disposing fluid at $15^{\circ} \mathrm{C}$ ), and LEG with closed loops. For both cases, a simplified regional procedure path was defined which excludes the latter type by the regional environmental screening, which is mandatory for the former type.

It was decided (L.D. 28/2011) that the next emanation of an implementation decree, called "geothermal probes installation decree", should have defined any technical and procedural detail of the low local geothermal energy use. As the "installation decree" still does not exist, Italy lacks a uniform regulatory framework for the regional or sub-regional (provincial) regulations.

At present, there are regional laws and/or regulations for nine regions (of twenty) on LEG, from north-west to south-east: Aosta Valley, Piedmont, Lombardy, Trentino Alto Adige, Veneto, Emilia Romagna, Tuscany, Umbria, Latium, and Campania (Figure 2). In some of these regions, sub-regional provincial regulations were defined, as in the case of Veneto and Trentino Alto Adige, with a provincial gap in the case of Veneto. The complex Italian constitutional order includes some special provinces, called autonomous provinces. Their juridical rank is like the regional one: it concerns the Trento and Bolzano autonomous provinces, the union of which correspond to the Trentino Alto Adige Region. 
The geographical distribution of existing regulations reflects the differences in development in favor of the central-northern part of the country.

A synthetic overview of different Italian regional and sub-regional regulations can be useful both to understand the Italian system and for future regulation improvements to be realized everywhere (Table 2). The resulting picture is quite uneven. There are macroscopic differences in the LEG systems, authorization procedures, competent authorities and, not described in details for sake of brevity, required technical documentation for completing instances.

Table 2. Italian framework of local LEG regulations. Institutions: $\mathrm{R}=$ region; $\mathrm{Pr}=$ province or $\mathrm{M}=$ metropolitan town (a recent regulation for the main national towns which includes the whole province); $\mathrm{A}=$ autonomous (which is a special autonomous status for some region or province). Reference: $\mathrm{RL}=$ regional law; $\mathrm{RR}=$ regional regulation; $\mathrm{RD}=$ regional decree; $\mathrm{RCD}=$ regional council decree; $\mathrm{MD}=$ management decree; $\mathrm{PL}=$ provincial law; $\mathrm{PR}=$ provincial resolution; $\mathrm{WPP}=$ water protection plan. Installation: $\mathrm{P}=$ heating or cooling power; $\mathrm{D}=$ probe depth or length; $\mathrm{N}=$ number of probes; $\mathrm{OL}=$ opened loop; $\mathrm{CL}=$ closed loop; $\mathrm{G}=$ ground level. Procedure: SCIA = certified notification of starting activity (signed by owner and professional expert); RRLI = Regional register of LEG installation; GRT = ground response test.

\begin{tabular}{|c|c|c|c|c|c|}
\hline \multicolumn{2}{|c|}{$\begin{array}{l}\text { Regional or Provincial } \\
\text { Institutions: Name and } \\
\text { Type (R, P, M, A) }\end{array}$} & $\begin{array}{l}\text { Regulatory } \\
\text { Reference }\end{array}$ & System Classes & $\begin{array}{c}\text { Installation } \\
\text { Characteristics } \\
P(\mathrm{~kW}),(\mathrm{N}),(\mathrm{D}, \mathrm{m}) \\
(\mathrm{G}, \mathrm{m} \text { asl })\end{array}$ & Authorization Procedure \\
\hline \multirow{3}{*}{$\begin{array}{l}\text { Aosta } \\
\text { Valley }\end{array}$} & \multirow{3}{*}{$\mathrm{R}$} & RL 26/2012 & Small & $\mathrm{P}<50 \mathrm{~kW}$ & SCIA and geological consulting/reporting \\
\hline & & \multirow{2}{*}{ RL 13/2015 } & Medium & $50<\mathrm{P}<1 \mathrm{MW}$ & $\begin{array}{l}\text { As "small" plus technical assessment of the } \\
\text { Regional mining service }\end{array}$ \\
\hline & & & Large & $\mathrm{P}>1 \mathrm{MW}$ & As "medium" plus Conference of services \\
\hline \multirow[b]{2}{*}{ Lombardy } & \multirow[b]{2}{*}{$\mathrm{R}$} & RL 24/2006 & Small & $\mathrm{P}<50 \mathrm{~kW}$ and $\mathrm{D}<150 \mathrm{~m}$ & Registration on RRLI \\
\hline & & $\frac{\text { RR 7/2010 }}{\text { RD 9072/2010 }}$ & Large & $\mathrm{P}>50 \mathrm{~kW}$ or $\mathrm{D}>150 \mathrm{~m}$ & $\begin{array}{l}\text { As "small" plus Pr or M authorization which } \\
\text { requires GRT }\end{array}$ \\
\hline \multirow{2}{*}{ Piedmont } & \multirow{2}{*}{$\mathrm{R}$} & \multirow{2}{*}{ MD 66/2016 } & Small & $\mathrm{P}<50 \mathrm{~kW}$ and $\mathrm{N}<10$ & Pr or M authorization \\
\hline & & & Large & $\mathrm{P}>50 \mathrm{~kW}$ or $\mathrm{N}>10$ & As "small" plus GRT \\
\hline \multirow{4}{*}{ Bolzano } & \multirow{4}{*}{$\operatorname{Pr}, \mathrm{A}$} & \multirow{4}{*}{$\begin{array}{l}\text { PL } 8 / 2002 \\
\text { PR } 321 / 2018\end{array}$} & \multirow{2}{*}{ Small } & $\mathrm{P}<100 \mathrm{~kW}$ & $\begin{array}{l}\text { Application/procedure at the Province (Water } \\
\text { resources management Office) }\end{array}$ \\
\hline & & & & $\mathrm{D}<200 \mathrm{~m}$ & GRT for systems with $\mathrm{P}>50 \mathrm{~kW}$ \\
\hline & & & \multirow{2}{*}{ Large } & $\mathrm{P}>100 \mathrm{~kW}$ & \multirow{2}{*}{ Environmental assessment procedure } \\
\hline & & & & $\mathrm{D}>200 \mathrm{~m}$ & \\
\hline \multirow[t]{2}{*}{ Trento } & \multirow{2}{*}{$\operatorname{Pr}, \mathrm{A}$} & \multirow{2}{*}{ PR 1593/2013 } & & & $\begin{array}{l}\text { Prior communication specifying place, owner, } \\
\text { contractor, installation specifications, and, if D } \\
\quad>150 \mathrm{~m} \text {, technical reporting }\end{array}$ \\
\hline & & & & & $\begin{array}{l}\text { Final communication to the Geological Service, } \\
\text { with stratigraphic and technical data }\end{array}$ \\
\hline Veneto & $\mathrm{R}$ & WPP, 2009 & & & The regulation is delegated to each province \\
\hline \multirow{3}{*}{ Venice } & \multirow{3}{*}{ M } & \multirow{3}{*}{ PR 47/2011 } & 1 & $\mathrm{P}<50 \mathrm{~kW}$ & $\begin{array}{l}\text { Authorization application to the Soil } \\
\text { Conservation Service }\end{array}$ \\
\hline & & & 2 & $50<\mathrm{P}<100 \mathrm{~kW}$ & As "1" plus GRT and hydrogeological study \\
\hline & & & 3 & $\mathrm{P}>100 \mathrm{~kW}$ & $\begin{array}{l}\text { As "2" plus 15-year transient thermal } \\
\text { modelling simulation }\end{array}$ \\
\hline \multirow{3}{*}{ Belluno } & \multirow{3}{*}{$\operatorname{Pr}$} & \multirow{3}{*}{$\begin{array}{l}\text { Guidelines } \\
\text { (upgraded on } \\
\text { CTPA 476/4 } \\
2016 \text { decision) }\end{array}$} & \multirow{2}{*}{$\mathrm{A}$} & \multirow{2}{*}{$\mathrm{P}<35 \mathrm{~kW}$} & $\begin{array}{l}\text { Authorization application to the Water and } \\
\text { environment Sector, including technical reports }\end{array}$ \\
\hline & & & & & $\begin{array}{l}\text { At the end of installation, certified regular } \\
\text { work execution }\end{array}$ \\
\hline & & & B & $\begin{array}{l}\mathrm{P}>35 \mathrm{~kW} \text { or } \\
\mathrm{G}>800 \mathrm{~m} \text { asl }\end{array}$ & As "A" plus recommended GRT \\
\hline \multirow{4}{*}{ Rovigo } & \multirow{4}{*}{$\operatorname{Pr}$} & & 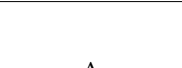 & $\mathrm{P}-501 \mathrm{t}$ & $\begin{array}{l}\text { Authorization application to the Water and } \\
\text { environment Sector, including technical reports }\end{array}$ \\
\hline & & PR 23-33643/2011 & A & $P<50 \mathrm{kWV}$ & $\begin{array}{l}\text { At the end of installation, certified regular } \\
\text { work execution }\end{array}$ \\
\hline & & & B & $50<\mathrm{P}<100 \mathrm{~kW}$ & As "A" plus GRT and hydrogeological study \\
\hline & & & $\mathrm{C}$ & $\mathrm{P}>100 \mathrm{~kW}$ & $\begin{array}{l}\text { As "B" plus 15-year transient thermal } \\
\text { modelling simulation }\end{array}$ \\
\hline
\end{tabular}


Table 2. Cont.

\begin{tabular}{|c|c|c|c|c|c|}
\hline \multicolumn{2}{|c|}{$\begin{array}{l}\text { Regional or Provincial } \\
\text { Institutions: Name and } \\
\text { Type }(R, P, M, A)\end{array}$} & $\begin{array}{l}\text { Regulatory } \\
\text { Reference }\end{array}$ & System Classes & $\begin{array}{c}\text { Installation } \\
\text { Characteristics } \\
\mathrm{P}(\mathrm{kW}),(\mathrm{N}),(\mathrm{D}, \mathrm{m}) \\
(\mathrm{G}, \mathrm{m} \text { asl })\end{array}$ & Authorization Procedure \\
\hline \multirow[b]{2}{*}{ Treviso } & \multirow[b]{2}{*}{$\operatorname{Pr}$} & \multirow{2}{*}{$\begin{array}{c}\text { PR } \\
27-107532 / 2012\end{array}$} & A & $\mathrm{P}<50 \mathrm{~kW}$ & $\begin{array}{l}\text { Authorization application to the Ecology and } \\
\text { environment Sector and Municipality }\end{array}$ \\
\hline & & & B & $\mathrm{P}>50 \mathrm{~kW}$ & $\begin{array}{l}\text { As "A" plus GRT and hydrogeological study } \\
\text { with 15-year transient thermal modelling } \\
\text { simulation and monitoring }\end{array}$ \\
\hline \multirow{3}{*}{ Verona } & \multirow{3}{*}{$\operatorname{Pr}$} & \multirow{3}{*}{$\begin{array}{l}\text { Provincial } \\
\text { Regulation } \\
\text { of } 2012\end{array}$} & 1 & $\mathrm{P}<50 \mathrm{~kW}$ & $\begin{array}{l}\text { Authorization application, including technical } \\
\text { reporting, to the Regional Directorate of } \\
\text { Geology and Geo-resources, Regional } \\
\text { Environmental Agency and Municipality }\end{array}$ \\
\hline & & & 2 & $50<\mathrm{P}<100 \mathrm{~kW}$ & As "1" plus GRT and hydrogeological study \\
\hline & & & 3 & $\mathrm{P}>100 \mathrm{~kW}$ & $\begin{array}{l}\text { As "2" plus 15-year transient thermal } \\
\text { modelling simulation }\end{array}$ \\
\hline \multirow{4}{*}{ Vicenza } & \multirow{4}{*}{$\operatorname{Pr}$} & \multirow{4}{*}{ PR 15/2015 } & 1 & $\mathrm{P}<30 \mathrm{~kW}$ & Online application to the Province \\
\hline & & & 2 & $30<\mathrm{P}<50 \mathrm{~kW}$ & As "1" \\
\hline & & & 3 & $50<\mathrm{P}<100 \mathrm{~kW}$ & As “1" plus GRT \\
\hline & & & 4 & $P>100 \mathrm{~kW}$ & $\begin{array}{c}\text { As " } 3 \text { " plus hydrogeological study with } \\
\text { 15-year transient thermal modelling simulation } \\
\text { and monitoring }\end{array}$ \\
\hline \multicolumn{2}{|c|}{ Emilia-Romagna R } & \multicolumn{2}{|l|}{ RR 41/2001 } & & $\begin{array}{c}\text { Application to the Municipality and the River } \\
\text { Basin Authority }\end{array}$ \\
\hline Tuscany & $\mathrm{R}$ & RL 39/2005 & & & SCIA \\
\hline Umbria & $\mathrm{R}$ & RCD 386/2010 & & & Application to the Municipality or the Province \\
\hline \multirow{5}{*}{ Latium } & \multirow{5}{*}{$\mathrm{R}$} & \multirow{5}{*}{$\begin{array}{l}\text { RL 3/2016 e RCD } \\
\text { 385/2018 }\end{array}$} & \multirow[b]{2}{*}{$\begin{array}{l}\text { Existing } \\
\text { building, } \mathrm{CL}\end{array}$} & $\begin{array}{l}\mathrm{P}<100 \mathrm{~kW} \text { and } \\
\mathrm{D}<120 \mathrm{~m}\end{array}$ & $\begin{array}{l}\text { Communication to the Municipality and } \\
\text { registration on RRLI }\end{array}$ \\
\hline & & & & $\begin{array}{c}\mathrm{P}<100 \mathrm{~kW} \text { and } 120 \\
<\mathrm{D}<400 \mathrm{~m} \\
\text { or } \\
100<\mathrm{P}<500 \mathrm{~kW} \text { and } \\
\mathrm{D}<120 \mathrm{~m}\end{array}$ & As previous case plus SCIA to the Province \\
\hline & & & $\begin{array}{c}\text { New } \\
\text { building, CL }\end{array}$ & $\begin{array}{l}\mathrm{P}<100 \mathrm{~kW} \text { and } \\
\quad \mathrm{D}<120 \mathrm{~m}\end{array}$ & SCIA to the Province and registration on RRLI \\
\hline & & & Any building, CL & $\mathrm{P}>500 \mathrm{~kW}$ & SCIA to the Province and registration on RRLI \\
\hline & & & $\begin{array}{l}\text { Any building, } \\
\text { OL, balanced or } \\
\text { not, on } \\
\text { groundwater or } \\
\text { surface water }\end{array}$ & $\mathrm{P}<2 \mathrm{MW}$ and $\mathrm{D}<400 \mathrm{~m}$ & Water utilization concession \\
\hline Campani & $\mathrm{R}$ & RL 5/2013 & & $\mathrm{P}<1 \mathrm{MW}$ and $\mathrm{D}<200 \mathrm{~m}$ & Simplified procedure \\
\hline
\end{tabular}

The very wide range of type of reference or regulatory sources (regional and provincial laws, decrees, management decrees), competent institution, and of authorization procedure, different from a region or province to another one, require detailed knowledge of local rules. This is a huge limitation for professionals and companies. It should be avoided to promote LEG's widespread diffusion and the awareness of the full compatibility with sustainability and safety.

The system classification considers one or more of these parameters: power, type of building (existing or new), altitude, and, in the case of vertical loop, depth of installation, number of probes (vertical closed loop). Apart from the probe number, these parameters seem useful to guide and prioritize checking procedures. There are also very simple regulations (Autonomous Province of Trento, Emilia Romagna, Tuscany and Umbria) which do not use a system classification or the classification is so wide and generic as to be almost useless (i.e., the Campania Region case) (Table 2).

The use of thematic maps for LEG authorization planning, as in the case of French experience, is negligible, with the praiseworthy exceptions of mapping tools of Vicenza Province, which are included in the regulation documents, of Autonomous Province of Trento, which uses a "Restraints Map", periodically upgraded to include new environmental information and knowledge.

Focusing on interesting procedures, the cases of the mandatory request of ground response tests (GRTs), detailed hydrogeological site studies, and 15-year transient thermal modelling simulation in 
the case of LEG with higher potential impacts seem to be relevant. The registration obligation on a regional register (database) seems a very good idea that could be further enhanced if it became a mandatory basis to assess overlapping effects of nearby LEG systems.

All regulations concern the check of few or several conditions before LEG system installation. Rare but important is the idea to check the operational LEG effects with monitoring, for large system but also in the case of installation with non-negligible risks. Checking procedures for LEG decommissioning do not exist.

The most recent geothermal regulation was defined by Latium Region (regional law RL 3/2016), which introduces different regulations for new and modern building with respect to existing buildings and for open loop. Both choices seem very good ideas for areas with relevant historical heritages and to manage better the use of groundwater or surface waters for opened loops, respectively. In the latter case, the regulation distinguishes balanced solutions, in which the full flow of used water is discharged in the natural source, or unbalanced solutions. The unbalanced solutions should be avoided as much as possible, pursing sustainable solutions, expecting peculiar situations to be checked with environmental screening.

The Latium regulation is the only one that considers the LEG radon hazard for human health, forbidding (in the earlier, now repealed, version) vertical LEG where radon concentration is higher than $300 \mathrm{~Bq} / \mathrm{m}^{3}$. The radon hazard is a relevant issue in Latium, where geogenic sources of radon are active, but the drilling LEG contribution to this hazard should be very low and can be easily nullified by adopting rigorous borehole sealing treatments [21,22]. The definition of a (low, respectful of local natural conditions) threshold without exception for sealing solutions, seems to be contradicting the purpose to promote LEG sustainable widespread diffusion. The threshold criterium was modified in 2017 (RL 9/2017), moving to a more generic prohibition where "abnormal leakage of endogenic gases" could be dangerous to human health. That regulatory modification has not definitely solved the problem, confirming further research efforts are still needed to achieve improved design guidelines for environmental protection and human safe combination in the LEG systems topic.

The result of the absence of a national specific regulation has been a framework of procedures with heterogeneous authorization instruments of different rank (guidelines, regulations, regional laws, etc.), developed at regional (or autonomous province) level and, with reference to the implementing regulations, also at provincial level.

\section{Discussion and Conclusions}

If the paper and whole research discuss the Italian situation in detail, international experiences offer many interesting results. The use of English and Italian keywords could justify an overestimation of European and Italian experiences but not the inhomogeneous interest to LEG applications at the global scale. English is the global language for scientific articles and technical standards and is the legal language for the maximum number of countries in the world (Italian is the fourth foreign language studied in the world and the twenty-first spoken language) (https://www.habitante.it). On these bases, the inaccuracy between countries should be low, and very low between groups of countries using or not using English as a legal language. Checking other global factors, it seems realistic that national social and economic conditions and natural conditions prone to geo-exchange could contribute to explain this variability (https://worldmapper.org, https://www.whymap.org/), from the global view to the regional Italian differences.

Given the many differences in regulations, both at international and national level, there is a general need to revise, update, and/or provide a more complete geographical coverage of regulations, more exhaustive for types and classes of installations.

Regulations should be locally and globally operative, easy to apply, and useful to guide LEG characteristic selection respecting local environmental characteristics and geo-hydrological potential risks. 
Regulations are more frequent, from the global to the local scale, for open-loop systems, as they are considered a potential source of conflicts with other water uses. These regulations are always released in the framework of the water utilization regulation.

The EU experience shows that many countries have no specific legislation on LEG as an effect of the lack of binding EU directives. Technical standards can be very useful to support LEG design and installation activities, partially solving some problems in the case of lack of official regulation (www.iso.org, www.vdi.de, www.uni.com).

Comparing all experiences, two paths can be schematized: general framework regulation (GFR) or local framework regulation (LFR).

The former case is the case of a union of governmental institutions (i.e., states or nations; regions, cantons, or lander) for which a unique framework regulation includes detailed guidelines and/or maps to guide optimal LEG design, installation, maintenance, and decommissioning. More detailed local regulations could be useful to consider specific climate or geo-hydrological conditions.

The latter case corresponds to a governmental institution (i.e., a union of state, a federal country) which recognizes the right to sub-governmental institutions to define local regulations without a superordinate framework.

LFR seems more respectful of the governmental autonomies and more quickly achievable but the practical experience at European scale shows that this choice creates delays and ineffective or absent regulations. These results are clearly confirmed by the Italian experience, in which many regions are devoid of regulation while other regions use regulations with sub-regional details and differences. All these problems create difficulties for professionals and companies and reduce public awareness of advantages of LEG utilization.

GFR seems the optimal choice. It should provide detailed guidelines to single sub-governmental institutions, permitting them to apply guidelines according to their geological peculiarities, improving the local regulatory framework, with reference to every technical and environmental aspects. Guidelines prevent spatial regulation gaps in the case of sub-governmental delays and prevent environmental conflicts or, worse, damages where regulation is absent or too low detailed.

GFR promotes homogeneous definitions, system classifications and procedures. The Swiss regulation system seems to be the experience which is better compliant with GFR conceptualization. Different but very effective seems to be the French system, which is based on the use of a national system of thematic maps with enough information also at the local scale. In the case of EU and Italian experiences, evident are the negative effects of guidelines, planned but not published in the latter case.

Whatever the regulatory framework could be, some common characteristics should be included.

The regulation should consider LEG hazard contribution during installation, utilization, and/or decommissioning.

The optimal sustainable development of LEG requires careful assessments of impacts, consequent limitations or prescriptions, according to geological, hydrogeological, and environmental site-specific characteristics of the area.

At the global level or at EU level, a shared guideline about all possible risks of low enthalpy geothermal plant should be drawn up, including aspects that are generally neglected by most regulations (i.e., biological effects and endogenic gases) but which at local level and/or in big realizations could be relevant.

At local level, evidence-based policy could consider all potential risks or a part of those following territorial conditions.

The use of the thematic maps on hazardous local conditions seems the optimal choices. From the database study, a list of main hazards of LEG applications can be summarized (Table 3). 
Table 3. Summary of hazard sources to be considered for LEG.

\begin{tabular}{|c|c|c|}
\hline Category & Sub-Category & Hazards \\
\hline \multirow{2}{*}{ Caves } & Natural cave & \multirow{2}{*}{$\begin{array}{l}\text { Cave enlargement or worsening of } \\
\text { stability conditions }\end{array}$} \\
\hline & Anthropogenic caves, mining activity & \\
\hline \multirow{4}{*}{ Groundwater } & Artesian or confined aquifer & \multirow{4}{*}{$\begin{array}{l}\text { Quality or quantity degradation of } \\
\text { groundwater resources, hydrogeological } \\
\text { balance worsening }\end{array}$} \\
\hline & Shallow or phreatic aquifer & \\
\hline & Multi-strata aquifer & \\
\hline & Hydrogeological protection zone & \\
\hline \multirow{2}{*}{ Landslides and floods } & Landslide-prone areas & \multirow{2}{*}{$\begin{array}{l}\text { Specific hazard worsening and potential } \\
\text { value and damage increase }\end{array}$} \\
\hline & Flooding-prone areas & \\
\hline \multirow[t]{2}{*}{ Soil and rock instability } & $\begin{array}{l}\text { Compressible and clayey soils and } \\
\text { subsidence }\end{array}$ & \multirow{2}{*}{$\begin{array}{c}\text { Worsening of rocky mechanical } \\
\text { characteristics and rock masses instability } \\
\text { and stability }\end{array}$} \\
\hline & Karstification and evaporitic rocks & \\
\hline \multirow{2}{*}{ Pollution } & Antifreeze additives & \multirow{2}{*}{ Soil and water pollution } \\
\hline & Polluting constructive and boring material & \\
\hline $\begin{array}{l}\text { Biochemistry and } \\
\text { microbiology }\end{array}$ & $\begin{array}{l}\text { Microbiological variations, biodegradation } \\
\text { and/or organic matter effects }\end{array}$ & $\begin{array}{l}\text { Worsening of ecological equilibria in natural } \\
\text { protected areas }\end{array}$ \\
\hline Endogenous gas occurrence & Gas outflow & Human health \\
\hline
\end{tabular}

The mandatory procedure requirements should be standardized everywhere and proportional to LEG system classes, possible overlapping effects, and area vulnerability characteristics, considering main hazards and less occurring hazards if relevant.

In the case of LEG with higher potential impacts or in the case of installation in areas with some potential hazards or in natural protected areas, it seems relevant the mandatory request of ground response tests (GRTs), detailed hydrogeological site studies, and 15-year transient thermal modelling simulation [23]. The request of environmental or hydrogeological monitoring during the operation period could be an optimal solution for very large LEG systems, or in the case of public concern about potential hazard, as in the case of natural protected areas.

A public-owned array of sensors, installed in a network of private and public systems, could be useful to monitor the overall availability of the resource to prevent overexploitation and use-conflicts in areas where geothermal systems are particularly widespread.

The registration obligation on a global register, the LEG installation database, seems a very good idea that could be further enhanced if it became a mandatory basis to assess overlapping effects of nearby LEG systems.

The potential natural risks could be a sort of common denominator to align different standards and regulations and to ensure, on a global scale, equal development opportunities, environmental protection, and conflict prevention in the use of ground heat resource following the sustainable development principle of "no one will be left behind."

The best way to share available knowledge on LEG-related hazards is to realize a thematic map at a sufficient scale to consider any hazard type as a very useful tool for private and public institutions interested to LEG system implementation.

Capitalizing on these remarks, the authors, which include staff members of the Apulian Regional Council, have planned further activities concerning the Apulia region. The study could be considered as pre-normative research to achieve evidence-based policy indications about regulatory design on the low enthalpy geothermal topic [24]. A detailed discussion of each type of classified risk will be completed, considering geological and hydrogeological situ-specific peculiarities, together with any possible solution to permit fully safe and environmentally sustainable LEG installation, including deployment details. The detailed study of geological and hydrogeological regional peculiarities with respect to LEG-related hazards is ongoing, including monitoring activities on test sites. The main Apulian 
peculiarities are: the widespread prevalence of karstic features due to which the availability of water surface resources is low; groundwater resources being the main regional water source; landslide- and flood-prone areas are not negligible; many natural protected areas cover the region and many of them correspond to groundwater-dependent ecosystems [25-28]; the radon presence in enclosed spaces is considered a health risk and this issue is governed by a specific regulation (RL 30/2016).

The mapping activity is integrating the regional conceptualization with a litho-stratigraphic column approach, capitalizing on the long-lasting expertise of the research group on geological, geotechnical, and hydrogeological Apulian peculiarities and the CNR-IRPI databases. Twelve litho-stratigraphic columns were distinguished to conceptualize the whole region up to a maximum depth of $125 \mathrm{~m}$, which is generally the maximum depth for LEG systems realized in the region. This maximum has been selected using a cost-benefit criterion, due to the maximum commercial length of tubes which are available for probes but, from a methodological point of view, can be easily modified or increased.

Using this conceptualization together with other significant layers, as flood and landslide hazard maps, groundwater and aquifers thematic maps, HPZs, and natural protected areas, the region will be distinguished in areas with absent or specified potential LEG-related hazards (Table 3).

This mapping information system will be used to distinguish three types of zones: 1 or green, 2 or orange, and 3 or red. Zone 1 will be based on LEG information sharing, without relevant restriction or procedures. Zone 2 will require specific requirements to be defined for each single mapped potential hazard. In any case, a detailed geo-hydrological study will be mandatory, which could include numerical simulations. Zone 3 will correspond to the prohibition zone, as imposed by very high hazards and/or overlapping hazardous conditions for which there will not be sufficient technical solutions to realize safe LEG systems.

Author Contributions: Documental analysis, G.D.G., M.C., L.E.Z., A.R., P.P.L., V.D., M.P., R.P.; Statistical analysis of documents: L.E.Z.,V.D., M.P.; methodology, G.D.G., M.C., G.M., M.P.; writing-original draft preparation: G.D.G., A.R., L.E.Z., M.P.; writing—review: G.D.G., M.C., G.M., R.P., M.P.; Final editing: G.D.G., M.P.; Supervision: M.P.; Project administration: A.R., M.P., M.C., G.M.; Funding acquisition: G.M., A.R., M.P. All authors have read and agreed to the published version of the manuscript.

Funding: This research was co-funded by the Apulia Regional Council and the National Research Council-Research Institute for Hydrogeological Protection.

Conflicts of Interest: The authors declare no conflict of interest.

\section{References}

1. Parri, R.; Lazzeri, F.; Cataldi, R. Larderello: 100 years of geothermal power plant evolution in Italy. Geotherm. Power Gener. Dev. Innov. 2016, 537-590. [CrossRef]

2. Huttrer, G.W. The status of world geothermal power generation 1995-2000. Geothermics 2001, 30, 1-27. [CrossRef]

3. Lund, J.W.; Boyd, T.L. Direct utilization of geothermal energy 2015 worldwide review. Geothermics 2016, 60, 66-93. [CrossRef]

4. Sanner, B. Summary of EGC 2019 Country Update Reports on Geothermal Energy in Europe. In Proceedings of the European Geothermal Congress 2019, Den Haag, The Netherlands, 11-14 June 2019.

5. Rybach, L.; Sanner, B. Ground-Source Heat Pump Systems the European experience. GHC Bull. 2000, 21, 16-26.

6. Reay, D.; McGlen, R.; Kew, P. Heat Pipes_-Theory, Design and Applications, 6th ed.; Butterworth Heinemann: Oxford, UK, 2013; p. 288.

7. Muffler, P.; Cataldi, R. Methods for regional assessment of geothermal resources. Geothermics 1978, 7, 53-89. [CrossRef]

8. Lee, K.C. Classification of geothermal resources by exergy. Geothermics 2001, 30, 431-442. [CrossRef]

9. Moeck, I.S. Catalog of geothermal play types based on geologic controls. Renew. Sustain. Energy Rev. 2014, 37, 867-882. [CrossRef]

10. Casasso, A.; Sethi, R. Efficiency of closed loop geothermal heat pumps: A sensitivity analysis. Renew. Energy 2014, 62, 737-746. [CrossRef] 
11. Saner, D.; Juraske, R.; Kübert, M.; Blum, P.; Hellweg, S.; Bayer, P. Is it only CO2 that matters? A life cycle perspective on shallow geothermal systems. Renew. Sustain. Energy Rev. 2010, 14, 1798-1813. [CrossRef]

12. Blumsack, S.; Kleit, A.; Smith, S.W. Evaluation of federal and state subsidies for ground-source heat pumps. Energy Effic. 2012, 5, 321-334. [CrossRef]

13. Corniello, A.; Cardellicchio, N.; Cavuoto, G.; Cuoco, E.; Ducci, D.; Minissale, A.; Mussi, M.; Petruccione, E.; Pelosi, N.; Rizzo, E.; et al. Hydrogeological characterization of a geothermal system: The case of the thermo-mineral area of Mondragone (Campania, Italy). Int. J. Environ. Res. 2015, 9, 523-534. [CrossRef]

14. Lo Russo, S.; Civita, M.V. Hydrogeological and thermal characterization of shallow aquifers in the plain sector of Piemonte region (NW Italy): Implications for groundwater heat pumps diffusion. Environ. Earth Sci. 2010, 60, 703-713. [CrossRef]

15. Busoni, S.; Destro, E.; Galgaro, A. Geoscambio nella provincia di Treviso. Provincia di Treviso Servizio, Ecologia e Ambiente. 2012. Available online: http://ecologia.provincia.treviso.it/Engine/RAServeFile.php/f/ Pubblicazioni/5344/Geoscambio_nella_provincia_di_Treviso.pdf (accessed on 25 March 2020).

16. Abate, S.; Aldighieri, B.; Ardizzone, F.; Barnaba, F.; Basso, A.; Botteghi, S.; Caielli, G.; Calvi, E.; Caputi, A.; Caputo, M.C.; et al. VIGOR: Sviluppo Geotermico nella Regione Puglia—Studi di Fattibilità a Bari e Santa Cesarea Terme. In Progetto VIGOR_Valutazione del Potenziale Geotermico delle Regioni della Convergenza, POI Energie Rinnovabili e Risparmio Energetico 2007-2013; CNR-IGG: Pisa, Italy, 2015; ISBN 9788879580168.

17. Casasso, A.; Sethi, R. Territorial analysis for the implementation of geothermal heat pumps in the province of Cuneo (NW Italy). Energy Procedia 2015, 78, 1159-1164. [CrossRef]

18. Chicco, J.; Fusari, A.; Chiara Invernizzi, C. Innovative applications of geothermal energy for direct uses: A pilot study case in Marche region (Italy). Rend. Online Soc. Geol. Ital. 2016, 41, 280-283. [CrossRef]

19. Haehnlein, S.; Bayer, P.; Blum, P. International legal status of the use of shallow geothermal energy. Renew. Sustain. Energy Rev. 2010, 14, 2611-2625. [CrossRef]

20. Tsagarakis, K.P.; Efthymiou, L.; Michopoulos, A.; Mavragani, A.; AnCelkovi, A.S.; Antolini, F.; Bacic, M.; Bajare, D.; Baralis, M.; Bogusz, W.; et al. A review of the legal framework in shallow geothermal energy in selected European countries: Need for guidelines. Renew. Energy 2018, 147, 2556-2571. [CrossRef]

21. Cinelli, G.; Tositti, L.; Capaccioni, B. Soil gas radon assessment and development of a radon risk map in Bolsena, Central Italy. Environ. Geochem. Health 2015, 37, 305-319. [CrossRef] [PubMed]

22. Bossew, P.; Cinelli, G.; Ciotoli, G.; Crowley, Q.G.; De Cort, M.; Elío Medina, J.; Gruber, V.; Petermann, E.; Tollefsen, T. Development of a Geogenic Radon Hazard Index-Concept, History, Experiences. Int. J. Environ. Res. Public Health 2020, 17, 4134. [CrossRef]

23. De Giorgio, G.; Chieco, M.; Zuffianò, L.E.; Limoni, P.; Sottani, A.; Pedron, R.; Vettorello, L.; Stellato, L.; Di Rienzo, B.; Polemio, M. The Compatibility of Geothermal Power Plants with Groundwater Dependent Ecosystems: The Case of the Cesine Wetland (Southern Italy). Sustainability 2018, 10, 303. [CrossRef]

24. Bruno, D.E.; Caputo, M.; Chieco, M.; Uricchio, V.F. The definition of regulations and transparent procedures for authorizations to promote the low enthalpy geothermal: The Vigor project's contribution. Geo Italia Epitome 2011, 3, 383.

25. Polemio, M.; Lonigro, T. Trends in climate, short-duration rainfall, and damaging hydrogeological events (Apulia, Southern Italy). Nat. Hazards 2015, 75, 515-540. [CrossRef]

26. Polemio, M. Monitoring and Management of Karstic Coastal Groundwater in a Changing Environment (Southern Italy): A Review of a Regional Experience. Water 2016, 8, 148. [CrossRef]

27. De Giorgio, G.; Zuffianò, L.E.; Polemio, M. The role of the hydrogeological and anthropogenic factors on the environmental equilibrium of the Ugento Wetland (Southern Italy). Rend. Online Soc. Geol. Ital. 2019, 47, 79-84. [CrossRef]

28. Tinti, F.; Pangallo, A.; Berneschi, M.; Tosoni, D.; Rajver, D.; Jovanović, D.; Rudinica, T.; Jelisić, S.; Zlokapa, B.; Raimondi, A.; et al. How to boost Shallow Geothermal Energy exploitation in the Adriatic area: The LEGEND project experience. Energy Policy J. 2016, 92, 190-204.

Publisher's Note: MDPI stays neutral with regard to jurisdictional claims in published maps and institutional affiliations. 